\title{
Influence of Problem Based Learning Models (PBL) and Learning Motivation to Learn Outcomes and Student's Critical Thinking Skills Themes of Caring for Life in Class IV Primary School No 026609 Pujidadi Binjai
}

\author{
Muhammad Rizki Utomo', Hasruddin², Abdul Murad ${ }^{3}$ \\ ${ }^{1,2,3}$ Universitas Negeri Medan, Indonesia
}

\begin{abstract}
The results obtained from this study include the learning outcomes of students in the experimental class and control class, the students 'critical thinking skills in the experimental class and the control class as well as the observation data of students' learning motivation on the theme of caring for living beings in grade IV Elementary School 026609 Pujidadi Binjai in the 2019 academic year. /2020. shows that the average score of learning motivation in the experimental class is 82.20 with a standard deviation of 6.823 and the average score of learning motivation in the control class is 45.23 with a standard deviation of 1.007. Furthermore, the results of the students' learning motivation scores between the experimental class and the control class are combined then the median is sought. This process is carried out to divide motivation into two groups, namely the high motivation group with the criteria of students with a motivation score above the middle value (median) and the low motivation group with the criteria of students with a motivation score below the middle value. As for the calculation, the median value is 63.71. The research method used is Quasi Experimental Quasi (Quasi Experimental Method) with the research design as the basisfor the implementation of the research is to distinguish the effect of problem-based learning models and the effect of expository learning on student outcomes and critical thinking skills in science in terms of high learning motivation and low learning motivation. the treatment class is class V1 class V2.
\end{abstract}

Keywords

learning; motivation; student's critical; problem based

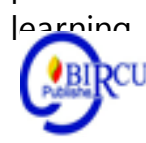

\section{Introduction}

Education is a process of development, formation, and guidance practical training for humans through appropriate guidance and guidance throughout his life. According to law No. 20 of 2003 on the system national education states that national education functions develop capabilities and shape the character and civilization of the nation dignified in order to educate the nation's life. Educational aims to develop the potential of students to become believers and fear God Almighty, have a noble character, are healthy, knowledgeable, competent, creative, independent, and a democratic citizen as well responsible (BSNP, 2011: 39).

Education is very important in the change and development of the Indonesian nation for the better. In accordance with the opinion of Trianto (2011: 1) "Education that is able to support future development is education that is able to develop the potential of students, so that they are able to face and solve life problems they face". 


\section{Review of Literatures}

Education aims to make students happy and make the lives of students better in the future and to achieve happiness in the world and the hereafter based on faith, knowledge, and charity. One of the efforts to improve the quality of education is through improving the teaching and learning process, which contains a series of teacher and student actions on the basis of reciprocal relationships that take place in educational situations to achieve certain goals in the learning process. In realizing these educational goals, the most important thing is how to foster children's personality and diversity.

According to Amri (2010: 51) that "Education does not expect human beings who become alienated from their community, but through education it is hoped that they can better understand and be able to develop the lives of their people". Therefore, the objectives, content, and process of education must be in accordance with the needs, conditions, characteristics, wealth and developments in society. In coaching and improving to achieve educational goals an important role is the role of school teachers. School is the second place in a student's life. Schools are formal educational institutions that have a systematic program in carrying out guidance, teaching and training to children (students) so that they develop according to their potential.

Learning according to Rusman (2012: 1) is a system, which consists of various components that are interconnected with one another. These components include: objectives, materials, methods, and evaluation. The four components must be considered by the teacher in selecting and determining the learning model to be used. Selection of the right learning model can have a positive impact on student mastery of the subject matter being taught and student learning outcomes. According to Fred (in Djamarah 2006: 61) he has conducted research on 3,725 students in the United States. From the results of his research states that, "If you use good methods and good media in teaching and learning activities, it will get good learning outcomes".

According to Sitorus (2020) Learning management strategies are very important in the overall learning strategy system. However the planning of the organizing strategy and the learning delivery strategy are good, but if the management strategy is not considered, the effectiveness of learning.

Based on the results of observations of the average UAS score at SD 026609 Pujidadi Binjai for the 2019/2020 academic year, it shows that the average acquisition of student learning outcomes is still low below the KKM determined by the school as shown in Table 1.

Table 1. Value of Students' Natural Science Semester Exam Results Class IV Elementary School 026609 Pujidadi Binjai

\begin{tabular}{ccccc}
\hline No & Class & $\begin{array}{c}\text { Students } \\
\text { Completed }\end{array}$ & Not complete & Percentage \\
\hline 1 & V1 & 13 & 8 & $62 \%$ \\
\hline 2 & V2 & 15 & 6 & $71 \%$ \\
\hline & amount & 28 & 14 & $67 \%$ \\
\hline
\end{tabular}

According to Arsani (2020), learning is essentially a cognitive process that has the support of psychomotor functions. Low learning outcomes and students' critical thinking skills are also influenced by low student motivation. The importance of motivation in the learning process because it can arouse and increase the enthusiasm of students in learning. Uno (2008: 29) states that "one of the most influential variables on learning outcomes is 
student characteristics including the level of learning motivation". Given that motivation is a driving force in action, if students lack intrinsic motivation, it requires external encouragement, namely extrinsic motivation so that students are motivated to learn. According to Wulandari (2020) learning motivation can describe the processes that can bring up and encourage behavior, provide direction and purpose of behavior and can determine whether or not good in achieving goals so that the greater the motivation will be greater learning success. In order for the basic competencies and learning objectives that are expected to be achieved properly, a scientific learning model is needed. This model is intended to provide learning experiences to students so that students are able to build their own knowledge so that the knowledge lasts a long time in the minds of students. One model that is able to cover all these characteristics is the problem-based learning model (PBL).

According to Simanjuntak (2020) The teacher is a very important factor in determining the success of the learning process, therefore the teacher must be able to increase student learning motivation so that students play an active role in the learning process so that they are expected to achieve good quality education.

Based on the limitation of the problems that have been stated above, the problem of this research can be formulated as follows: (1) Is there an effect of the problem-based learning model on student science learning outcomes in the theme of caring for living beings in grade IV Elementary School 026609 Pujidadi Binjai. (2) Is there a motivational effect on student science learning outcomes on the theme of Concern for Living Beings in grade IV Elementary School 026609 Pujidadi Binjai. (3) Is there an interaction between the influence of the learning model and motivation on students' science learning outcomes in the Theme of Concern for Living Things in grade IV Elementary School 026609 Pujidadi Binjai. (1) Is there an effect of the problem-based learning model on students' critical thinking science skills in the theme of caring for living beings in grade IV Elementary School 026609 Pujidadi Binjai. (2) Is there any influence of motivation on students' critical thinking skills in Natural Science on the theme of Concern for Living Creatures class IV Elementary School 026609 Pujidadi Binjai. (3) Is there an interaction between the influence of the learning model and motivation on students' critical thinking skills in Natural Science in the theme of Caring for Living Beings in grade IV Elementary School 026609 Pujidadi Binjai.

Based on the problem formulation above, this research has several objectives which can be described as follows: (1) To determine the effect of problem-based learning models on student science learning outcomes in the theme of caring for living beings in class IV Elementary School 026609 Pujidadi Binjai. (2) To determine the effect of motivation on students' science learning outcomes on the theme of Concern for Living Beings in grade IV Elementary School 026609 Pujidadi Binjai. (3) To find out the interaction between learning models and motivation on students' science learning outcomes in the theme of caring for living beings in grade IV Elementary School 026609 Pujidadi Binjai. (4) To find out the effect of problem-based learning models on students' critical thinking skills in science in the theme of caring for living beings in grade IV Elementary School 026609 Pujidadi Binjai. (5) To determine the effect of motivation on students' critical thinking skills in Natural Science on the theme of Concern for Living Beings in grade IV Elementary School 026609 Pujidadi Binjai. (6) To find out the interaction between learning models and motivation on students' critical thinking skills in Science in the Themes of Concern for Living Things in grade IV Elementary School 026609 Pujidadi Binjai. 


\section{Research Method}

This research was conducted at Elementary School 026609 Jalan Sei Babalan, Pujidadi Village, South Binjai, Binjai City, Zip code 20727 in the odd semester of the 2019/2020 Learning Year. The research schedule is planned to be carried out in accordance with the schedule for entering science subjects and teachers who teach in giving treatment are science subject teachers in class IV Elementary School 026609 Pujidadi Binjai. The reasons for the establishment of the 026609 Pujidadi Binjai Elementary School as a place for conducting research are: (1) The school has the availability of supporting learning facilities and facilities; (2) There has never been a similar research conducted in that school; and (3) the need to apply a new learning paradigm where so far the learning that has been carried out tends to use the expository method and has never applied a problem-based learning model; and (4) The school is very open to research that can improve learning.

The population of this study were students of class IV Elementary School 026609 Pujidadi Binjai Academic Year 2019/2020 with 2 classes totaling 50 students. Each class has the same characteristics, meaning that each student uses the same curriculum. The study population is as in Table 2 below:

Table 2. The Study Population

\begin{tabular}{ccc}
\hline No & Class & The Number of students \\
\hline $\mathbf{1 .}$ & $\mathrm{V}-1$ & 21 Students \\
$\mathbf{2 .}$ & $\mathrm{V}-2$ & 21 Students \\
\hline & Total & 42 Students
\end{tabular}

The sample in this study was taken by total sampling (saturated sampling). Sugiyono (2013: 81) states that "saturated sampling is a sampling technique when all populations are used as samples". The experimental class V1, totaling twenty-five students (21), was taught with problem-based learning (PBL) and the V2 control class, totaling twenty-five students (21), was taught using expository learning. The research method used is Quasi Experimental Quasi (Quasi Experimental Method) with the research design as the basis for the implementation of the research is to distinguish the effect of problem-based learning models and the effect of expository learning on student outcomes and critical thinking skills in science in terms of high learning motivation and low learning motivation. the treatment class is class V1 class V2.

Before being given the treatment, the researcher first gave a pretest to each class with the aim of knowing the students' initial abilities without being influenced by learning. The treatment was given to the experimental class, namely the class with PBL and the class using expository learning. The determination of the experimental class was done by lottery. The teacher who gave the treatment was chosen by two people and drawn to determine which experimental class to teach. Before the teacher teaches, they are first given an explanation of the implementation of the treatment they will do, and the learning environment is strived to be the same. In the implementation of the treatment there is no differentiation between groups who have high and low motivation. Grouping was only given at the time of data analysis, likewise students who were not selected as samples still received the same treatment as the sample, but were not analyzed. This type of research is a quasi-experimental research, which aims to determine whether there is a result of a treatment imposed on students, namely students. 


\section{Discussion}

\subsection{Understanding Learning Outcomes}

In learning activities carried out by a person, it cannot be separated from the results as a continuation of the learning efforts he does. Sometimes someone is also said to be successful in their learning activities, if the results they get are very good or satisfying. Learning outcomes can be explained by understanding the two words that make up it, namely "results" and "learning". The definition of the result (product) indicates the acquisition of the result of an activity or process that results in changes in functional input. Production results are the gains obtained due to the activity of converting raw materials into finished goods. According to Dimyati (2013: 10) "learning is a complex activity in the internal state and cognitive processes of students" with a stimulus from the environment ". According to Hamid (2013: 2) Learning outcomes are changes in behavior that occur after the teaching and learning process is in accordance with educational goals. Humans have the potential for psychological behavior that can be educated and their behavior changes which include the cognitive, affective, and psychomorotic domains. Learning to seek behavioral changes in these domains so that learning outcomes represent behavioral changes in the cognitive, affective and psychomorotic domains.

\subsection{Factors Affecting Learning Outcomes}

Learning is a process that causes a change based on experience. Thus there are many things or aspects that affect or are involved in the teaching and learning process and these factors also have an influence on student learning outcomes or achievement. According to Khairani (2013: 188), "the factors that cause learning difficulties can be classified into two groups, namely: internal factors (self-factors in humans), which include physiological factors and psychological factors, external factors (factors from outside humans). include: non-social factors and social factors.

\subsection{Definition of Problem Based Learning}

Sutikno (2009: 31) states "Learning as a set of actions designed to support the learning process of students, by taking into account external events that play a role in a series of internal events that take place within students". In the learning process, the teacher is no longer an information center (teacher centered), but as a learning manager who is always ready to guide and assist students in learning. For example, group learning intends to create group dynamics so that the quality of learning increases. In group learning the number of quality students is expected to be greater. If the teacher's attention in individual learning is focused on each individual, then the teacher's attention in group learning is focused on the spirit of the group in solving problems. "Highly skilled" group members become the driving force for group problem solvers. The role of teachers in group learning consists of (i) forming groups, (ii) planning group assignments, (iii) implementing them, and (iv) evaluating group learning outcomes (Fakhriyah, 2014: 3).

\subsection{Characteristics of Problem Based Learning}

Problem-based learning is the use of various kinds of intelligence that are needed to perform a confrontation against real-world challenges, the ability to deal with everything new and existing complexities. The characteristics of problem-based learning are as follows: (1) Problems become the starting point in learning; (2) The problems raised are problems that exist in the real world that are not structured; (3) Problems require multiple perspectives; (4) 
Problems, challenging knowledge possessed by students, attitudes. And competencies which then require the identification of learning needs and new areas of learning; (5) Learning self direction is the main thing; (6) Utilization of various knowledge sources, their use, and evaluation of information sources are essential processes in PBM; (7) Learning is collaborative, communicative, and cooperative; (8) Development of inquiry and problem solving skills is as important as mastering the content of knowledge to find solutions to a problem; (9) The openness of the process in PBM includes the synthesis and integration of a learning process; and (10) PBM involves evaluating and reviewing student experiences and the learning process.

\subsection{Problem Based Learning Objectives}

According to Rusman (2012: 242) suggests problem-based learning objectives (PBM) in more detail, namely: (1) helping students develop thinking and problem-solving skills; (2) learn various adult roles through their involvement in real experiences; and (3) become autonomous students. PBM is used depending on the objectives to be achieved whether it is related to: (1) mastery of multidisciplinary content of knowledge; (2) mastery of process skills and heuristic discipline; (3) learn problem solving skills; (4) learn collaborative skills; and (5) learning broader life skills (Rusman, 2012: 248). When the objectives of PBM are broader, the problems become more complex and the PBM process requires a longer cycle. The type of PBM that will be included in the curriculum depends on the profile and maturity of the student, the student's past experience, flexibility, the existing curriculum, evaluation guidance, time, and available resources. PBM engages students in self-selected investigations that allow them to interpret and explain real-world phenomena and build their understanding of those phenomena.

\subsection{Problem-Based Learning Steps}

According to Rusman (2010: 74) "PBM begins with an unstructured problem, something chaotic. From this chaos, students use their various intelligences through discussion and research to determine real issues that exist. The steps that will be followed by students in a PBM process are: (1) finding the problem; (2) define the problem; (3) collect facts using the KND; (4) hypotheses; (5) research; (6) rephrasing the problem; (7) presenting alternatives; and (8) propose a solution ". According to Arends (2008: 72) states that: "There are 7 steps that must be passed in problem-based learning, namely as follows: (1) Clarifying unclear terms and concepts, (2) Formulating problems; (3) Analyze the problem; (4) Organize your ideas and systematically analyze them deeply; (5) Formulating learning objectives; (6) Seek additional information from other sources (outside of group discussions); and (7) Synthesize (combine) and test new information ". According to the above opinion it can be stated that the steps for problem-based learning are as follows: (1) Asking the problem; (2) Orienting students to learn; (3) Guiding individual and group investigations, (4) Developing and presenting the work; and (5) Analyzing and evaluating the problem-solving process.

\subsection{Advantages and Weaknesses of Based Learning Models Problem}

Sanjaya (2008: 220) states that problem-based learning has advantages in learning. Following are the advantages of problem-based learning: (1) Techniques are not good enough for understanding the content of the lesson; (2) Challenging students' abilities and providing satisfaction to discover new knowledge of students; (3) Increase student learning activities; (4) Helping students how to transfer their knowledge to understand problems in real life; (5) Helping students develop new knowledge and be responsible for the learning they do; (6) 
Encourage students to self-evaluate both the results and the learning process; (7) Show students that every subject (especially mathematics) is basically a way of thinking, and something that must be understood by students, not only learning from teachers or from books; (8) More fun and liked by students; (9) Provide opportunities for students to apply the knowledge they have in the real world; and (10) Developing students' interest in continuing to learn even though learning in formal education has ended. Sanjaya (2008: 220) states that problem-based learning (PBM) has weaknesses in learning. The following are the weaknesses of problem based learning: (1) When students have no interest or do not have the belief that the problem being studied is difficult to solve, they will feel reluctant to try; (2) It takes a long time, and (3) Without understanding they will not learn what they want to learn.

The results obtained from this study include the learning outcomes of students in the experimental class and control class, the students 'critical thinking skills in the experimental class and the control class as well as the observation data of students' learning motivation on the theme of caring for living beings in grade IV Elementary School 026609 Pujidadi Binjai in the 2019 academic year. / 2020 .

The following shows the data on the pretest results from the experimental class that was taught using the PBL learning model based on motivation and the control class that was taught using the Expository learning model. The data description of the pretest results is presented in Table 3:

Table 3. Data on Pretest Value of Learning Outcomes in Experiment and Control Class

\begin{tabular}{cccccc}
\hline Score & Frequency & $\begin{array}{c}\text { Relative } \\
\text { Frequency } \\
(\boldsymbol{\%})\end{array}$ & Score & Frequency & $\begin{array}{c}\text { Relative Frequency } \\
(\boldsymbol{\%})\end{array}$ \\
\hline $10-19$ & 0 & 0 & $10-19$ & 1 & 4,8 \\
\hline $20-29$ & 1 & 4,8 & $20-29$ & 3 & 14,3 \\
\hline $30-39$ & 6 & 28,6 & $30-39$ & 11 & 52,4 \\
\hline $40-49$ & 8 & 38,1 & $40-49$ & 5 & 23,7 \\
\hline $50-59$ & 4 & 19,5 & $50-59$ & 1 & 4,8 \\
\hline $60-69$ & 2 & 9,0 & $60-69$ & 0 & $\mathbf{1 0 0}$ \\
\hline Total & $\mathbf{2 1}$ & $\mathbf{1 0 0}$ & Total & $\mathbf{2 1}$ & $\mathbf{3 3 , 5 7}$ \\
\hline Average & $\mathbf{4 3 , 8 1}$ & Average & & \\
\hline
\end{tabular}

Table 3 shows that the students' initial knowledge of the material cares for the environment, it is known that the average pretest result for the experimental class was 43.81 and the average pretest result for the control class was 33.57. Furthermore, the two groups were given different treatment, namely the experimental group was taught using PBL based on motivation, while the control group was taught using the Expository learning model. At the end of the meeting, the learning process was given postes to determine the learning outcomes. The post-test results are presented in Table 4:

Table 4. Posttest Value of Student Learning Outcomes

\begin{tabular}{lcccccc}
\hline \multicolumn{1}{c}{ Class } & Lowest & $\begin{array}{c}\text { The } \\
\text { highest }\end{array}$ & Amount & Average & $\begin{array}{c}\text { Standard } \\
\text { Deviation }\end{array}$ & Variance \\
\hline Eksperimen & 70 & 100 & 2392,0 & 81,67 & 7.800 & 60,833 \\
\hline Kontrol & 55 & 85 & 2056,0 & 72,14 & 8.742 & 76,429 \\
\hline
\end{tabular}


Table 4 shows that the experimental group that was taught with the motivation-based PBL learning model obtained an average post-test result of 81.67 with a standard deviation of 7,800. Meanwhile, the control class that was taught using Expository obtained an average post-test result of 72.14 with a standard deviation of 8,742. From Table 4.2 it can be seen that the average learning outcomes of the experimental class students were higher than the average learning outcomes of the control class.

In addition, learning that emphasizes the development of process skills means guiding students to acquire skills in acquiring knowledge and presenting the results (Rustaman, 2005: 35). Learning with the PBL model contains activities that can train students to learn independently through investigations both at school and in the surrounding environment.

Research by applying the problem-based learning model (PBL) is in line with the results of research by Hardiyanti et al. (2017) which states that in applying the problem-based learning model there is a difference in $\mathrm{N}$-gain science process skills of 0.71 and in the control class (lecture and discussion methods). ) $\mathrm{N}$-gain of 0.52 . This is because the problem based learning (PBL) model facilitates students to construct their own knowledge from understanding the existence of a problem to solving the problem. The influence of the problem based learning model on science process skills in this research is also in line with the research of Handika and Muhammad (2013) which states that the problem based learning model is better than the conventional model on science process skills, this can be seen from the results of their research where SD ( $\operatorname{sig}=0.000<0.05$ ).

The significant difference in this study is in line with the research of Yoo, et al. (2015) which revealed that the PBL model effectively trains graduate nurses to improve their clinical problem-solving abilities compared to the lecture model. In addition, Angkotasan's research (2013) states that the PBL model is very effective when applied to learning to solve mathematical problems. Most of the problem based learning models are more widely used in Mathematics in the context of a particular subject. The problem based learning model is also very appropriate to be applied to other subjects, including science.

The findings of this study indicate that there is a significant interaction between the application of the problem-based learning model and the learning motivation of students. The interaction between the application of the PBL model and learning motivation occurs if both play a role in improving student learning outcomes. That is, if students who have high motivation are taught by applying good learning models such as the application of problembased learning models, then the learning outcomes obtained will be good too. The interaction graph shown through the help of SPSS 23.0 shows that the lines of interaction between the application of the problem-based learning model and the learning motivation of students almost intersect. Students who are taught by applying problem-based learning models and have high motivation for learning outcomes are also high, students who are taught by applying expository learning models with high motivation show lower learning outcomes than the application of high motivation problem based learning models. This shows that there is an interaction between the application of problem-based learning models with the learning motivation of students.

Such as the theory developed by Jean Piaget which views that every individual has the ability to construct his own knowledge by interacting continuously with his environment. This view denies that science is something that can be transferred. This study found that a group of students who were taught by applying a problem-based learning model with a high level of motivation with a group of students using a problem-based learning model with a low level of motivation obtained a significance value of 0.000 with prob. 0.05 so it can be concluded that there are differences in the application of problem-based learning models with high levels of motivation with groups of students with the application of problem-based 
learning models with low levels of motivation. This proves that the level of motivation of students affects student learning outcomes. In the same learning model, students who have high learning motivation get better results than students who have low learning motivation. The calculation of the Scheffe Test for groups of students who are taught by applying a high motivation problem-based learning model with the application of a high motivation Expository model obtained a significance value of 0.014 with prob. 0.05 , thus giving the decision to reject H0. Thus it is concluded that there are differences in the application of the learning model between the high motivation PBL model and the application of the high motivation Expository model.

Based on the data processing obtained, there are differences in the critical thinking skills of students who are taught with the problem-based learning model (PBL) with students who are taught using the Expository learning model where the average value of the learning outcomes of students who are taught with a problem-based learning model is higher, namely 80.86 with an average gain score of 0.63 while the average value of the group of students who were taught using the Expository learning model was 76.67 with an average gain score of 0.58 . This fact proves that the application of the problem-based learning model (PBL) is better at increasing the critical thinking skills of students than the application of the Expository learning model. Thus teaching Science on Animal Life Cycle material by applying the PBL model will be better than applying the Expository learning model. The learning process with this model students is directed to do several experiments repeatedly. This repeated and independent experiment aims to formulate and test hypotheses (PBL syntax), thereby fostering student activeness in asking questions and communicating their knowledge to their friends.

\section{Conclusion}

Based on the results of research and discussion, it can be concluded that several things are in accordance with the objectives of this study, namely: (1) The application of the problem-based learning model (PBL) can affect learning outcomes better than the Expository learning model. This is based on the results of the first hypothesis test that the significance of anava $(=0.000)$ is smaller than the significance level $(=0.05)$, and Fcount $(=27.273)$ is greater than Ftable $(=2.061)$ so that $\mathrm{H} 0$ is rejected, and also based on the average analysis. The average learning outcomes of students who apply the PBL model $(=81.67)$ are higher than students who apply the Expository model (= 72.14). (2) A high level of motivation can affect the learning outcomes of students better than low motivation. This is based on the results of the second hypothesis test that the significance of anava $(=0.002)$ is smaller than the significance level $(=0.05)$, and Fcount $(=37.322)$ is greater than Ftable $(=2.061)$ so that $\mathrm{HO}$ is rejected, and also based on the average analysis. Average learning outcomes of students based on the level of motivation to learn that the average learning outcomes of students who have high motivation $(=82.27)$ are higher than students who have low motivation $(=71.00)$. (3) There is an interaction between the application of the problem-based learning model (PBL) and the Expository learning model with the level of learning motivation in influencing learning outcomes. This is based on the results of the third hypothesis test that the significance of anava $(=0.008)$ is smaller than the significance level $(=0.05)$, and Fcount $(=$ $4.641)$ is greater than Ftable $(=2.061)$ so that $\mathrm{H} 0$ is rejected. (4) The application of the problem-based learning model (PBL) can affect critical thinking skills better than the Expository learning model. This is based on the results of the first hypothesis test that the significance of anava $(=0.006)$ is smaller than the significance level $(=0.05)$, and Fcount $(=$ 
$8.444)$ is greater than Ftable $(=2.061)$ so that $\mathrm{H} 0$ is rejected, and also based on the average analysis. The average learning outcomes of students who apply the PBL model $(=80.86)$ are higher than students who apply the Expository model $(=76.67)$. (5) High levels of motivation can affect students' critical thinking skills better than low motivation. This is based on the results of the second hypothesis test that the significance of anava $(=0.000)$ is smaller than the significance level $(=0.05)$, and Fcount $(=33.484)$ is greater than Ftable $(=2.061)$ so that $\mathrm{HO}$ is rejected, and also based on the average analysis. Average learning outcomes of students based on the level of motivation to learn that the average learning outcomes of students who have high motivation $(=82.73)$ are higher than students who have low motivation $(=74.40)$.

\section{References}

Arsani, et.al (2020). Differences in Motivational Orientation in Physical Education in terms of Gender Differences. Budapest International Research and Critics in Linguistics and Education (BirLE) Journal Volume 3, No 3, August 2020, Page: 1428-1434

Amri, S. 2010. Construction of Learning Development. Jakarta: Literature Achievement.

Angkotasan, N. 2013. PBL Model and Cooperative Learning Type TAI Viewed from the Aspect of Reflective Thinking Ability and Mathematical Problem Solving. Journal of Mathematics Education. 1 (8): 92-100

Arends, 2008. Learning To Teach Learning to Teach. Yogyakarta: Learning Library.

BSNP. 2011. Elementary School Education Unit Level Curriculum and Madrasah Ibtidaiyah. Jakarta: Depdiknas.

Dimyati. 2013. Learning and Learning. Jakarta: Rineka Cipta.

Djamarah. 2006. Teaching and Learning Strategies. Jakarta: Rineka Cipta.

Fakhriyah, F. 2014. Application of Problem Based Learning in Developing Students' Critical Thinking Ability. Journal of Indonesian Science Education, 3 (1): 95-101.

Handika, I \& Wangid, M. 2013. The Effect of Problem Based Learning on Mastery of Science Process Concepts and Skills. Prima Educasia Journal. I (1): 85-93.

Hamid, M. 2013. Relationship between Motivation and Economic Learning Achievement of Class VIII Students of SMP Negeri 2 Term Bireuen Regency. LENTERA, 13 (4): p. $12-21$.

Hardiyanti., Wardani \& Nurhayati. 2017. The Effectiveness of Problem Based Learning Model To Improve Science Process Skills. Journal of Chemical Education Innovation. 11 (1): 1862-1671

Khairani, M. 2013. Learning Psychology. Yogjakarta: Aswaja Pressindo.

Simanjuntak, L., Sriadhi, and Saragi, D. (2020). The Effect of Project Based Learning Models andLearning Motivation on Civics Learning Results in 4th Grade Primary School 106163 Percut Sei. Budapest International Research and Critics in Linguistics and Education (BirLE) Journal Vol 3 (3): 1509-1520.

Sitorus, L.S., Mardianto, and Matsum, H. (2020). Development of Powerpoint-Based Learning Media on Learning Aqeedah Morals. Budapest International Research and Critics in Linguistics and Education (BirLE) Journal Vol 3 (2): 958-964.

Wulandari, U.N., Ansari, K., and Hadi, W. (2020). The Effect of Cooperative Learning Models and Learning Motivation towards the Skills of Reading Students in Public Elementary School 101883 Tanjung Morawa Sub-district. Budapest International Research and Critics in Linguistics and Education (BirLE) Journal Vol 3 (2): 12091219. 